\title{
Short communication: Relationship between natural antibodies and postpartum uterine health in dairy cows
}

\author{
V. S. Machado, ${ }^{*}$ M. L. S. Bicalho, ${ }^{*}$ R. O. Gilbert, $†$ and R. C. Bicalho* ${ }^{* 1}$ \\ *Department of Population Medicine and Diagnostic Sciences, and \\ †Department of Clinical Sciences, College of Veterinary Medicine, Cornell University, Ithaca, NY 14853
}

\begin{abstract}
Postpartum uterine diseases of dairy cows compromise animal welfare and may result in early removal from the herd or impaired reproductive performance. The relationship between poor immune status around calving and uterine diseases is well established; however, that between natural antibodies (NAb) and uterine health has not yet been studied. The objective of this study was to evaluate the association of circulating $\mathrm{NAb}$ levels around parturition with puerperal metritis, clinical endometritis, and the intrauterine presence of the Escherichia coli virulence factor FimH. One hundred six pregnant heifers were enrolled; NAb in serum samples collected at $30 \pm 3 \mathrm{~d}$ prepartum and at $2 \pm 1$ and $35 \pm 3 \mathrm{~d}$ in milk (DIM) were measured by ELISA. Puerperal metritis was defined as the presence of fetid, watery, red-brown uterine discharge and rectal temperature $>39.5^{\circ} \mathrm{C}$ at $6 \pm 1$ DIM. Clinical endometritis was defined as presence of pus in the uterine lavage sample collected at $35 \pm 3$ DIM. The intrauterine presence of the fim $H$ gene at $2 \pm 1$ DIM was evaluated by PCR. The overall optical density (wavelength of 650 $\mathrm{nm}$ ) of ELISA-detected serum NAb was lower for cows diagnosed with puerperal metritis than for cows that did not have puerperal metritis. Additionally, cows diagnosed with clinical endometritis tended to have lower levels of NAb than did cows without clinical endometritis. Finally, FimH-positive cows had lower overall levels of serum NAb compared with FimH-negative cows. In conclusion, NAb detected in serum around parturition was associated with uterine health of dairy cows.
\end{abstract}

Key words: natural antibodies, metritis, endometritis, immune system

\section{Short Communication}

Postpartum uterine diseases of dairy cows are important for animal welfare and economic reasons because

Received May 20, 2014.

Accepted August 14, 2014.

${ }^{1}$ Corresponding author: rcb28@cornell.edu they contribute to cow discomfort, early removal from the herd, and reproductive failure. In North America, metritis affects 10 to $20 \%$ of cows (LeBlanc et al., 2011), whereas the incidence of endometritis is approximately $28 \%$, ranging from 5.3 to $52.6 \%$ (Dubuc et al., 2010; Cheong et al., 2012). Escherichia coli, Trueperella pyogenes, Bacteroides spp., and Fusobacterium necrophorum are the primary bacterial causes of uterine diseases (Dohmen et al., 1995; Miller et al., 2007; Bicalho et al., 2012). The virulence factor FimH, an E. coli type 1 pilus adhesive protein that plays a critical role in adhesion and colonization of epithelial surfaces (Mooi and de Graaf, 1985), is highly associated with uterine diseases and impaired reproductive performance in dairy cows (Bicalho et al., 2010, 2012).

The relationship between poor immune status around calving and uterine disease is already well established (Cai et al., 1994; Kimura et al., 2002; Kim et al., 2005; Hammon et al., 2006; Galvão et al., 2010), and recruitment of PMNL to the endometrial surface and the uterine lumen is critical for the immune defense of the uterus (Bondurant, 1999). However, these studies have focused only on the cellular component of the innate immune system.

Natural antibodies (NAb) are an important component of the humoral part of the innate immune system (Avrameas, 1991); they are present in the sera of normal, nonimmunized individuals (Sidman et al., 1986; Madi et al., 2009). They are produced by B-1 cells and spontaneously generated without the need for antigenic stimulation (Tarlinton et al., 1995). Natural antibodies can bind to pathogen-associated molecular patterns (Baumgarth et al., 2005), and they may represent the first line of defense by directly neutralizing the pathogen and activating the complement system (Ochsenbein and Zinkernagel, 2000). It has been reported that plasma NAb concentration is decreased during the periparturient period (van Knegsel et al., 2007), and higher levels of NAb tended to be associated with decreased risk of mastitis (Thompson-Crispi et al., 2013). However, to the best of our knowledge, the relationship between NAb and postpartum uterine health has not yet been studied. Therefore, the objective of this study 
was to evaluate the association between circulating $\mathrm{NAb}$ levels detected at $30 \pm 3 \mathrm{~d}$ prepartum and at $2 \pm$ 1 and $35 \pm 3$ DIM, the incidence of puerperal metritis and clinical endometritis, and the intrauterine presence of the $E$. coli virulence factor FimH.

This study was conducted from June 16 to November 16,2012 , in a commercial dairy farm located near Ithaca, New York, and 106 pregnant heifers were enrolled. Serum samples were collected from each cow 3 times during the study period: at $30 \pm 3 \mathrm{~d}$ prepartum and at $2 \pm 1$ and $35 \pm 3$ DIM. To obtain serum samples, blood was collected from the coccygeal vein or artery using a Vacutainer tube without anticoagulant and a 20-gauge $\times$ 2.54-cm Vacutainer needle (Becton Dickinson and Co., Franklin Lakes, NJ). After collection, all blood samples were transported to the laboratory on ice and centrifuged at $2,000 \times g$ for $15 \mathrm{~min}$ at $4^{\circ} \mathrm{C}$, and the serum was harvested and frozen at $-80^{\circ} \mathrm{C}$.

Puerperal metritis diagnosis was performed at $6 \pm 1$ DIM by the research team. Puerperal metritis was defined as the presence of fetid, watery, red-brown uterine discharge and rectal temperature $>39.5^{\circ} \mathrm{C}$ (Sheldon et al., 2006). Clinical endometritis was diagnosed at $35 \pm$ 3 DIM by visual inspection of a uterine lavage sample for the presence of purulent secretion, as described previously (Machado et al., 2012); clinical endometritis was defined by the presence of pus in the lavage sample. Body condition scores were determined for all study cows at $30 \pm 3 \mathrm{~d}$ prepartum and at $2 \pm 1$ and 35 \pm 3 DIM by a single investigator using a 5 -point scale with a quarter-point system as previously described (Edmonson et al., 1989).

Cervical swabs were collected at $2 \pm 1$ DIM for FimH detection by PCR; cows were restrained and the perineum area was cleansed and disinfected with $70 \%$ ethanol solution. The swab was manipulated inside the cervix and exposed to uterine secretion. The swabs were kept inside sterile vials at $4^{\circ} \mathrm{C}$ until processed in the laboratory. In the laboratory, swab samples were immersed in $1 \mathrm{~mL}$ of PBS in a $15-\mathrm{mL}$ Falcon tube and vortexed to disperse any mucus, bacteria, or cells. Total DNA was isolated from $400 \mu \mathrm{L}$ of the suspension by using a QIAmp DNA minikit (Qiagen, Santa Clara, CA) according to the manufacturer's instructions for DNA purification from blood and body fluids. Some convenient modifications, such as the addition of $400 \mu \mathrm{g}$ of lysozyme and incubation for $12 \mathrm{~h}$ at $56^{\circ} \mathrm{C}$, were included to maximize bacterial DNA extraction. Total DNA was eluted in 100 $\mu \mathrm{L}$ of sterile DNase- and RNase-free water (Promega, Madison, WI). The concentration and purity of DNA were evaluated by optical density using the Nanodrop ND-1000 spectrophotometer (Nanodrop Technologies, Rockland, DE), and the fimH gene was amplified by PCR. All reactions were performed in a $25-\mu \mathrm{L}$ volume using Green GoTaqMasterMix (Promega), 10 pmol of primers (forward: TGCAGAACGGATAAGCCGTGG; reverse: GCAGTCACCTGCCCTCCGGTA), and $1 \mu \mathrm{L}$ of DNA extract. All thermal cycling protocols were performed in a 2720 Thermal Cycler (Applied Biosystems, Foster City, CA); the thermal cycling protocol was $95^{\circ} \mathrm{C}$ for $12 \mathrm{~min}$, followed by 25 cycles at $94^{\circ} \mathrm{C}$ for $30 \mathrm{~s}$, $63^{\circ} \mathrm{C}$ for $30 \mathrm{~s}$, and $68^{\circ} \mathrm{C}$ for $3 \mathrm{~min}$, followed by a final extension at $72^{\circ} \mathrm{C}$ for $10 \mathrm{~min}$. Negative controls consisting of the PCR mixture without DNA were included in all PCR runs. Amplification products were separated by electrophoresis through a $1.2 \%(\mathrm{wt} / \mathrm{vol})$ agarose gel, stained with $0.5 \mu \mathrm{g} / \mathrm{mL}$ ethidium bromide, and visualized with a Kodak Gel Logic 100 Imaging System (GL 100, Scientific Imaging Systems, Eastman Kodak Co., New Haven, CT). Positive results were considered to be amplicons of $508 \mathrm{bp}$.

Because keyhole limpet hemocyanin (KLH) is a metalloprotein found in the hemolymph of the giant keyhole limpet, Megathura crenulata (Harris and Markl, 1999), dairy cattle are naive to it. Therefore, it is unlikely that it would be recognized by specific serum immunoglobulins of dairy cattle, which makes KLH a good antigen with which to measure NAb. Hence, NAb in the serum samples were measured by ELISA as follows: ELISA micro-titer plates (Greiner Bio-One, Frickenhausen, Germany) were coated with $0.1 M$ carbonate buffer $\mathrm{pH} 9.2$ containing $1 \mu \mathrm{g} / \mathrm{mL}$ of KLH (Sigma Aldrich, St. Louis, MO). Binding of antigen to microtiter wells was carried out overnight at $4^{\circ} \mathrm{C}$; nonspecific binding sites were blocked with PBS containing 3\% fish gelatin (Sigma Aldrich) for $3 \mathrm{~h}$ at room temperature. Dilutions of bovine serum samples were then added to the ELISA plates; serum samples were diluted in proportions of 1:40 in PBS containing $0.5 \mathrm{M} \mathrm{NaCl}$ and $0.5 \%$ Tween-20. The serotype-specific antibody bound to the ELISA plate was detected with anti-bovine IgG antibody conjugated with horseradish peroxidase, diluted according to the manufacturer's instructions (Sigma Aldrich), followed by addition of the substrate, 3,3',5,5'-tetramethylbenzidine (TMB; Sigma Aldrich). The optical density (OD) of each well was measured after $20 \mathrm{~min}$ at $650 \mathrm{~nm}$ using an ELISA plate reader (Synergy HT microplate reader, BioTek Instruments, Winooski, VT). The amount of color produced was proportional to the amount of primary antibody bound to the protein on the bottom of the wells. The assays were performed in 3 wells for each sample; in 2 wells, the assays were performed in duplicate, as described above, and the third well was a blank. The blank well was prepared using the same steps performed in the duplicates, except that it was not coated with the antigen. Data were reported as OD at $650 \mathrm{~nm}\left(\mathbf{O D}_{650}\right)$, a result of the average OD of the 
sample duplicates minus the OD of its respective blank. Blanks were performed to minimize eventual variations in the data due to unspecific binding, including binding of serum antibodies to block. Between each step of the assay, the microtiter wells were aspirated and rinsed 3 times with washing solution (PBS containing $0.1 \%$ Tween-20).

Three mixed general linear models were fitted to the data using the MIXED procedure of SAS (SAS Institute Inc., Cary, NC). The dependent variable evaluated in these analyses was $\mathrm{OD}_{650}$ of ELISA-detected serum NAb. The model assumption of normally distributed residuals was satisfied by visual evaluation of the distribution plot of the studentized residuals. The data were longitudinally collected and comprised a series of repeated measures of the dependent variable throughout the 3 time points of serum collection: $30 \pm 3 \mathrm{~d}$ prepartum, $2 \pm 1 \mathrm{DIM}$, and $35 \pm 3$ DIM. To account appropriately for repeated measures, the error term was modeled by imposing a first-order autoregressive covariance structure for all statistical models. The independent variables offered to the first, second, and third models were puerperal metritis (yes or no), clinical endometritis (yes or no), and FimH (positive or negative). Body condition score at $30 \pm 3$-d prepartum, 2 $\pm 1 \mathrm{DIM}$, and $35 \pm 3 \mathrm{DIM}$ and time of serum collection were offered to all 3 models. Two-way and 3 -way interactions between uterine health parameters, BCS, and time of serum collection were offered to the models; variables and their respective interaction terms were retained in the models only when $P<0.10$.

The incidences of puerperal metritis and clinical endometritis were 12.1 and $8.6 \%$, respectively. Additionally, $10.5 \%$ of cows were positive for FimH at $2 \pm 1$ DIM. Of the cows diagnosed with puerperal metritis, $30.0 \%$ were positive for FimH and $10.0 \%$ were subsequently diagnosed with clinical endometritis. Additionally, $11 \%$ of cows diagnosed with endometritis were positive for FimH at $2 \pm 1$ DIM. The overall $\mathrm{OD}_{650}$ of ELISA-detected serum NAb was lower for cows diagnosed with puerperal metritis than for cows that did not have puerperal metritis: $0.30(\mathrm{SEM}=0.03)$ and $0.38(\mathrm{SEM}=0.01)$, respectively $(P=0.02$; Figure 1$)$. Furthermore, cows diagnosed with clinical endometritis tended to have lower overall $\mathrm{OD}_{650}$ of ELISA-detected serum NAb than cows without clinical endometritis: $0.28(\mathrm{SEM}=0.04)$ and $0.35(\mathrm{SEM}=0.01)$, respectively $(P=0.09$; Figure 2$)$. Finally, cows positive for FimH at $2 \pm 1$ DIM had lower overall OD $_{650}$ of ELISA-detected serum NAb than negative cows: $0.30(\mathrm{SEM}=0.03)$ and $0.38($ SEM $=0.01)$, respectively $(P=0.02$; Figure 3$)$.

In this study, we were able to detect NAb specific for KLH in serum of dairy cows, as previously described by others (van Knegsel et al., 2007; Ploegaert et al., 2010;

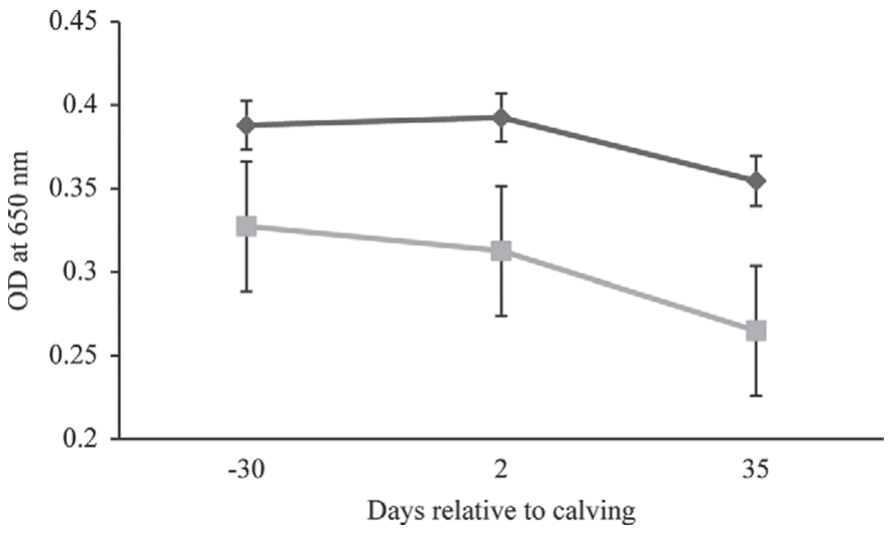

Figure 1. Serum natural antibodies (NAb) levels for cows diagnosed as having or not having puerperal metritis; the black line illustrates the average optical density at $650 \mathrm{~nm}\left(\mathrm{OD}_{650}\right)$ of ELISAdetected serum NAb for cows that did not have puerperal metritis, and the gray line illustrates the average $\mathrm{OD}_{650}$ of ELISA-detected serum NAb for cows that were diagnosed with puerperal metritis. The overall $\mathrm{OD}_{650}$ of ELISA-detected serum NAb was lower for cows diagnosed with puerperal metritis than for cows that did not have puerperal metritis $(P=0.02)$. The interaction between the variable puerperal metritis (yes or no) and time of serum collection was not significant $(P$ $=0.83)$. Error bar represent the standard error of the means.

Banos et al., 2013). Here, we report an association between higher circulating levels of serum NAb around parturition and decreased incidence of puerperal metritis or clinical endometritis. Additionally, the intrauterine presence of the $E$. coli virulence factor FimH at $2 \pm 1$ DIM, a primary condition for the occurrence

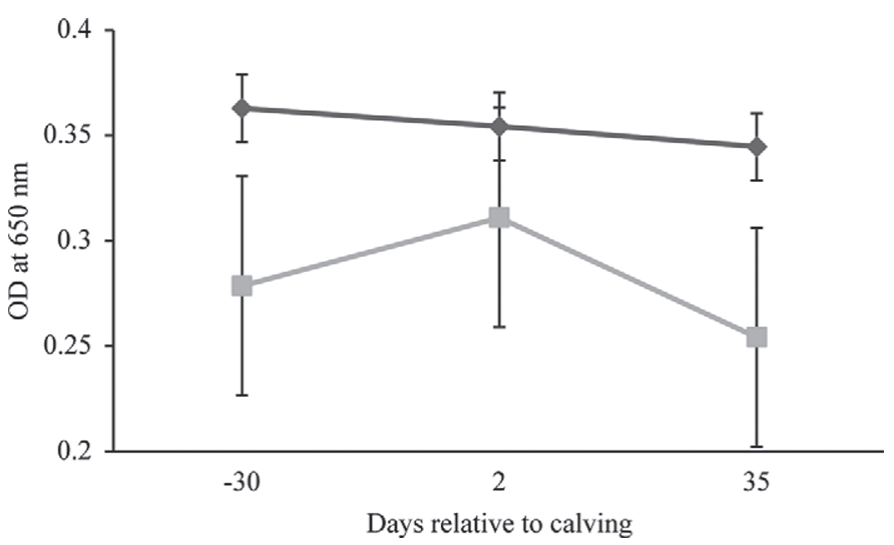

Figure 2. Serum natural antibodies (NAb) levels for cows diagnosed as having or not having clinical endometritis; the black line illustrates the average optical density at $650 \mathrm{~nm}\left(\mathrm{OD}_{650}\right)$ of ELISAdetected serum NAb for cows that did not have clinical endometritis, and the gray line illustrates the average $\mathrm{OD}_{650}$ of ELISA-detected serum NAb for cows that were diagnosed with clinical endometritis. The overall $\mathrm{OD}_{650}$ of ELISA-detected serum NAb tended to be lower for cows diagnosed with clinical endometritis than for cows that did not have clinical endometritis $(P=0.09)$. The interaction between the variable clinical endometritis (yes or no) and time of serum collection was not significant $(P=0.56)$. Error bars represent the standard error of the means. 


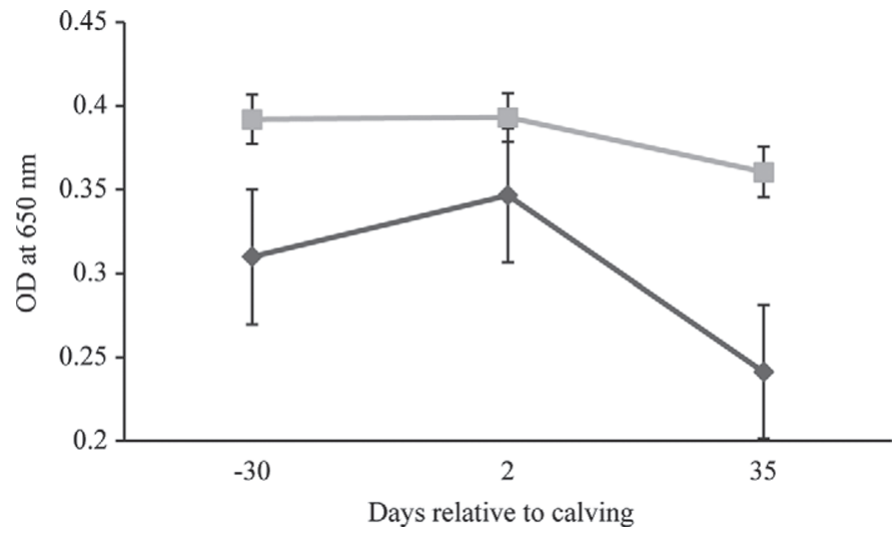

Figure 3. Serum natural antibodies (NAb) levels for cows positive or negative for the intrauterine presence of the Escherichia coli virulence factor FimH; the black line illustrates the average optical density at $650 \mathrm{~nm}\left(\mathrm{OD}_{650}\right)$ of ELISA-detected serum NAb for cows tested positive for $\mathrm{FimH}$, and the gray line illustrates the average $\mathrm{OD}_{650}$ of ELISA-detected serum NAb for cows that were tested negative. The overall $\mathrm{OD}_{650}$ of ELISA-detected serum NAb was lower for FimH-positive cows than for FimH-negative cows $(P=0.02)$. The interaction between the variable FimH (positive or negative) and time of serum collection was not significant $(P=0.19)$. Error bars represent the standard error of the means.

of uterine diseases and reproductive failure (Bicalho et al., 2010, 2012), was associated with lower serum $\mathrm{NAb}$ levels. Previous studies have suggested that the recruitment of PMNL to the endometrial surface and the uterine lumen is critical for the immune defense of the uterus (Cai et al., 1994; Hammon et al., 2006). Although immunoglobulins are not necessary for phagocytosis of bacteria by PMNL, immunoglobulins markedly increase the phagocytic activity of PMNL (Gondwe et al., 2010; Atosuo and Lilius, 2011). Our results suggest that NAb may play an important role in uterine disease resistance, perhaps by supporting phagocytosis by PMNL (Singh et al., 2008), directly neutralizing the pathogen, and activating the complement system (Ochsenbein and Zinkernagel, 2000), decreasing the intrauterine presence of fimbriated $E$. coli after parturition, thus contributing to clearance of infection of the uterus, and subsequently decreasing the incidence of puerperal metritis and clinical endometritis.

Admittedly, the correlation between circulating and intrauterine NAb levels is not known; however, previous studies have suggested that most of the immunoglobulins found in the uterine secretion of cattle are serum derived (Corbeil et al., 1974; Butt et al., 1993). The idea that antibodies may play an important role in uterine disease resistance is partly supported by a previous study, in which it was reported that systemic immunization against important intrauterine pathogens increased blood levels of specific antibodies and decreased the incidence of puerperal metritis (Machado et al., 2014).
Limited work has been performed to evaluate the associations between $\mathrm{NAb}$ and disease resistance in dairy cattle. In a study evaluating the association of circulating NAb levels with udder health, it was found that higher levels of IgM anti-KHL NAb tended to be associated with decreased risk of clinical mastitis, whereas no association was found with NAb of the IgG isotype (Thompson-Crispi et al., 2013). Additionally, NAb have been reported to have a negative association with elevated serum NEFA concentrations (van Knegsel et al., 2007, 2012), suggesting a relationship between metabolic health and NAb. The same relationship has been observed between metabolic status and the cellular component of the innate immune system; poorer metabolic status around parturition has been associated with compromised PMN killing ability (Hammon et al., 2006; Ster et al., 2012). Additionally, cows that developed metritis or endometritis had more impaired PMN function than healthy cows (Cai et al., 1994; Hammon et al., 2006). Here we suggest that decreased circulating NAb concentration is another factor that may contribute to the impairment of the innate immune system around parturition, increasing the risk of uterine diseases development.

It is possible that NAb does not play an active role in promoting uterine health and is simply acting as a biomarker of overall immune competence, as has been suggested previously (Banos et al., 2013). Interestingly, previous studies have reported relatively high heritability estimates for NAb, ranging from 0.10 to 0.53 (Ploegaert et al., 2010; Thompson-Crispi et al., 2013), suggesting that NAb could be used as an additional tool in genetic selection for disease resistance in cattle. In conclusion, results presented in this study demonstrate an association between higher circulating NAb around parturition and improved uterine health in dairy cows.

\section{REFERENCES}

Atosuo, J. T., and E. M. Lilius. 2011. The real-time-based assessment of the microbial killing by the antimicrobial compounds of neutrophils. ScientificWorldJournal 11:2382-2390. http://dx.doi. org $/ 10.1100 / 2011 / 376278$

Avrameas, S. 1991. Natural autoantibodies: From 'horror autotoxicus' to 'gnothi seauton'. Immunol. Today 12:154-159.

Banos, G., E. Wall, M. P. Coffey, A. Bagnall, S. Gillespie, G. C. Russell, and T. N. McNeilly. 2013. Identification of immune traits correlated with dairy cow health, reproduction and productivity. PLoS ONE 8:e65766.

Baumgarth, N., J. W. Tung, and L. A. Herzenberg. 2005. Inherent specificities in natural antibodies: A key to immune defense against pathogen invasion. Springer Semin. Immunopathol. 26:347-362.

Bicalho, M. L., V. S. Machado, G. Oikonomou, R. O. Gilbert, and R. C. Bicalho. 2012. Association between virulence factors of Escherichia coli, Fusobacterium necrophorum, and Arcanobacterium pyogenes and uterine diseases of dairy cows. Vet. Microbiol. 157:125-131.

Bicalho, R. C., V. S. Machado, M. L. Bicalho, R. O. Gilbert, A. G. Teixeira, L. S. Caixeta, and R. V. Pereira. 2010. Molecular and 
epidemiological characterization of bovine intrauterine Escherichia coli. J. Dairy Sci. 93:5818-5830.

Bondurant, R. H. 1999. Inflammation in the bovine female reproductive tract. J. Anim. Sci. 77(Suppl 2):101-110.

Butt, B. M., T. E. Besser, P. L. Senger, and P. R. Widders. 1993. Specific antibody to Haemophilus somnus in the bovine uterus following intramuscular immunization. Infect. Immun. 61:2558-2562.

Cai, T. Q., P. G. Weston, L. A. Lund, B. Brodie, D. J. McKenna, and W. C. Wagner. 1994. Association between neutrophil functions and periparturient disorders in cows. Am. J. Vet. Res. 55:934-943.

Cheong, S. H., D. V. Nydam, K. N. Galvao, B. M. Crosier, A. Ricci, L. S. Caixeta, R. B. Sper, M. Fraga, and R. O. Gilbert. 2012. Use of reagent test strips for diagnosis of endometritis in dairy cows. Theriogenology 77:858-864

Corbeil, L. B., G. D. Schurig, J. R. Duncan, R. R. Corbeil, and A. J. Winter. 1974. Immunoglobulin classes and biological functions of Campylobacter (Vibrio) fetus antibodies in serum and cervicovaginal mucus. Infect. Immun. 10:422-429.

Dohmen, M. J. W., J. A. C. M. Lohuis, G. Huszenicza, P. Nagy, and M. Gacs. 1995. The relationship between bacteriological and clinical findings in cows with subacute/chronic endometritis. Theriogenology 43:1379-1388.

Dubuc, J., T. F. Duffield, K. E. Leslie, J. S. Walton, and S. J. LeBlanc. 2010. Definitions and diagnosis of postpartum endometritis in dairy cows. J. Dairy Sci. 93:5225-5233.

Edmonson, A. J., I. J. Lean, L. D. Weaver, T. Farver, and G. Webster. 1989. A body condition scoring chart for Holstein dairy cows. J. Dairy Sci. 72:68-78.

Galvão, K. N., M. J. Flaminio, S. B. Brittin, R. Sper, M. Fraga, L. Caixeta, A. Ricci, C. L. Guard, W. R. Butler, and R. O. Gilbert. 2010. Association between uterine disease and indicators of neutrophil and systemic energy status in lactating Holstein cows. J. Dairy Sci. 93:2926-2937.

Gondwe, E. N., M. E. Molyneux, M. Goodall, S. M. Graham, P. Mastroeni, M. T. Drayson, and C. A. MacLennan. 2010. Importance of antibody and complement for oxidative burst and killing of invasive nontyphoidal Salmonella by blood cells in Africans. Proc. Natl. Acad. Sci. USA 107:3070-3075.

Hammon, D. S., I. M. Evjen, T. R. Dhiman, J. P. Goff, and J. L. Walters. 2006. Neutrophil function and energy status in Holstein cows with uterine health disorders. Vet. Immunol. Immunopathol. 113:21-29.

Harris, J. R., and J. Markl. 1999. Keyhole limpet hemocyanin (KLH): A biomedical review. Micron 30:597-623.

Kim, I. H., K. J. Na, and M. P. Yang. 2005. Immune responses during the peripartum period in dairy cows with postpartum endometritis. J. Reprod. Dev. 51:757-764.

Kimura, K., J. P. Goff, M. E. Kehrli Jr., and T. A. Reinhardt. 2002 Decreased neutrophil function as a cause of retained placenta in dairy cattle. J. Dairy Sci. 85:544-550.

LeBlanc, S. J., T. Osawa, and J. Dubuc. 2011. Reproductive tract defense and disease in postpartum dairy cows. Theriogenology $76: 1610-1618$

Machado, V. S., M. L. Bicalho, E. B. Meira Junior, R. Rossi, B. L. Ribeiro, S. Lima, T. Santos, A. Kussler, C. Foditsch, E. K. Ganda, G. Oikonomou, S. H. Cheong, R. O. Gilbert, and R. C. Bicalho. 2014. Subcutaneous immunization with inactivated bacterial com- ponents and purified protein of Escherichia coli, Fusobacterium necrophorum and Trueperella pyogenes prevents puerperal metritis in Holstein dairy cows. PLoS ONE 9:e91734.

Machado, V. S., W. A. Knauer, M. L. Bicalho, G. Oikonomou, R. O. Gilbert, and R. C. Bicalho. 2012. A novel diagnostic technique to determine uterine health of Holstein cows at 35 days postpartum. J. Dairy Sci. 95:1349-1357.

Madi, A., I. Hecht, S. Bransburg-Zabary, Y. Merbl, A. Pick, M. Zucker-Toledano, F. J. Quintana, A. I. Tauber, I. R. Cohen, and E. Ben-Jacob. 2009. Organization of the autoantibody repertoire in healthy newborns and adults revealed by system level informatics of antigen microarray data. Proc. Natl. Acad. Sci. USA 106:14484-14489.

Miller, A. N., E. J. Williams, K. Sibley, S. Herath, E. A. Lane, J. Fishwick, D. M. Nash, A. N. Rycroft, H. Dobson, C. E. Bryant, and I. M. Sheldon. 2007. The effects of Arcanobacterium pyogenes on endometrial function in vitro, and on uterine and ovarian function in vivo. Theriogenology 68:972-980.

Mooi, F. R., and F. K. de Graaf. 1985. Molecular biology of fimbriae of enterotoxigenic Escherichia coli. Curr. Top. Microbiol. Immunol. 118:119-138.

Ochsenbein, A. F., and R. M. Zinkernagel. 2000. Natural antibodies and complement link innate and acquired immunity. Immunol. Today 21:624-630.

Ploegaert, T. C., S. Wijga, E. Tijhaar, J. J. van der Poel, T. J. Lam, H. F. Savelkoul, H. K. Parmentier, and J. A. van Arendonk. 2010. Genetic variation of natural antibodies in milk of Dutch HolsteinFriesian cows. J. Dairy Sci. 93:5467-5473.

Sheldon, I. M., G. S. Lewis, S. LeBlanc, and R. O. Gilbert. 2006 Defining postpartum uterine disease in cattle. Theriogenology 65:1516-1530.

Sidman, C. L., L. D. Shultz, R. R. Hardy, K. Hayakawa, and L. A. Herzenberg. 1986. Production of immunoglobulin isotypes by Ly-1+ B cells in viable motheaten and normal mice. Science 232:1423-1425.

Singh, J., R. D. Murray, G. Mshelia, and Z. Woldehiwet. 2008. The immune status of the bovine uterus during the peripartum period. Vet. J. 175:301-309.

Ster, C., M. C. Loiselle, and P. Lacasse. 2012. Effect of postcalving serum nonesterified fatty acids concentration on the functionality of bovine immune cells. J. Dairy Sci. 95:708-717.

Tarlinton, D. M., M. McLean, and G. J. Nossal. 1995. B1 and B2 cells differ in their potential to switch immunoglobulin isotype. Eur. J. Immunol. 25:3388-3393.

Thompson-Crispi, K. A., F. Miglior, and B. A. Mallard. 2013. Genetic parameters for natural antibodies and associations with specific antibody and mastitis in Canadian Holsteins. J. Dairy Sci. 96:3965-3972

van Knegsel, A. T., G. de Vries Reilingh, S. Meulenberg, H. van den Brand, J. Dijkstra, B. Kemp, and H. K. Parmentier. 2007. Natural antibodies related to energy balance in early lactation dairy cows. J. Dairy Sci. 90:5490-5498.

van Knegsel, A. T., M. Hostens, G. de Vries Reilingh, A. Lammers, B. Kemp, G. Opsomer, and H. K. Parmentier. 2012. Natural antibodies related to metabolic and mammary health in dairy cows. Prev. Vet. Med. 103:287-297. 